\title{
Cultivation of microalgae for biofuel production: coupling with sugarcane- processing factories
}

\author{
Deribew Tefera Zewdie ${ }^{*}$ and Abubeker Yimam Ali
}

\begin{abstract}
Background: Despite their potential as biofuel resources, large-scale production of biofuels from microalgae is still uncertain primarily due to a lack of feasibility of the process and that it proves to be capital and energy intensive. Therefore, an integration of microalgal cultivation with other processes for achieving an inexpensive nutrient and energy use is an important issue. In the present study, the potential of the flue gas and the wastewater of a sugar factory to support microalgae growth for biofuel and bio-fertilizer production is evaluated.

Methods: The study was carried out by following a case study approach; an Ethiopian sugarcane-processing factory, Metahara sugar and ethanol production factory, was selected for this purpose. Conceptual microalgal biofuel production was integrated with the real sugarcane-processing factory, and the process was evaluated with regard to the product outputs and energy requirements.

Results: The integrated process model shows that three products, biodiesel, upgraded biogas, and bio-fertilizer with production capacities of 188 tons/year, 1,974,882 $\mathrm{m}^{3} /$ year and 42 tons/year, respectively, were produced. For the production of these products, the electricity and thermal energy demand of the integrated process amounted to 1822.13 and $3244.99 \mathrm{MWh} /$ year, respectively. A sensitivity analysis shows that the oil content of the algae, the nitrogen content of the waste, the oil extraction efficiency, and the transesterification efficiency are the main factors which affect the biodiesel production capacity of the integrated process.

Conclusions: This case study approach investigated the potential of a future possible bio-refinery and environmental pollution reduction concept by integrating microalgae biomass production with sugarcaneprocessing factory wastes and by-products. It was found that the factory wastes and by-products have a significant potential for a viable biofuel production from microalgae.
\end{abstract}

Keywords: Microalgae, Biofuel production, Sugar factory, Nutrients, Flue gas, Process integration

\section{Background}

Due to the diverse characteristics regarding biodiversity and elasticity of microalgae along with their higher growth rate compared with terrestrial plants, the ability to grow on non-productive land and use poor-quality water, the ability to remove pollutants from wastewater

\footnotetext{
* Correspondence: derbtef@yahoo.com

School of Chemical and Bioengineering, Addis Ababa Institute of Technology, Addis Ababa University, Addis Ababa, Ethiopia
}

and to sequester $\mathrm{CO}_{2}$ from flue gases, etc., microalgae have been considered as a promising future biofuel feedstock $[1,2]$. There are several pathways for processing microalgae into biofuel: biodiesel production through transesterification of lipids [3], bioethanol production through fermentation of the algal biomass, biogas production through anaerobic digestion, and bio-crude production through thermochemical conversion are among the alternatives processes [4-6]. Simultaneous

(c) The Author(s). 2020 Open Access This article is licensed under a Creative Commons Attribution 4.0 International License, which permits use, sharing, adaptation, distribution and reproduction in any medium or format, as long as you give appropriate credit to the original author(s) and the source, provide a link to the Creative Commons licence, and indicate if changes were made. The images or other third party material in this article are included in the article's Creative Commons licence, unless indicated otherwise in a credit line to the material. If material is not included in the article's Creative Commons licence and your intended use is not permitted by statutory regulation or exceeds the permitted use, you will need to obtain permission directly from the copyright holder. To view a copy of this licence, visit http://creativecommons.org/licenses/by/4.0/. The Creative Commons Public Domain Dedication waiver (http://creativecommons.org/publicdomain/zero/1.0/) applies to the data made available in this article, unless otherwise stated in a credit line to the data. 
production of biodiesel and biogas from microalgae has received interest as it enables the utilization of lipidextracted algae for further processing and biogas production so that it could help to enable a maximum utilization of the algae biomass [7, 8].

Anaerobic digestion has also become a special focus in the utilization of microalgae for biofuel production particularly from the bio-refinery point of view. For a viable production of biofuel from microalgae, some challenges, such as managing a high-energy and capital-intensive harvesting/dewatering process [9], coping with the high amount of residues left after lipid extraction in the case of lipid-based biofuel production (microalgae biomass contains $30-40 \%$ lipid, and up to $70 \%$ of the residual biomass is left after the extraction process) [10], and the need for fertilizers [11], need to be overcome. Anaerobic digestion can provide a pathway to avoid some of these problems by recovering nutrients from the extracted residual biomass and producing electricity from the methane biogas [12].

The production of biofuel from microalgae however has not yet been realized in large-scale production. Major research gaps, such as reducing energy input, maximizing yield, and those related to an efficient material and energy usage, are waiting to be addressed. In microalgae cultivation, the nutrient supply has a significant impact on cost, sustainability, and production sitings [13], whereas the major nutrients (nitrogen and phosphorous) need primary focus.

It has been reported that the integration of microalgal biofuel production with industrial or power plants might help to increase the feasibility of the process $[7,8]$. The aim of this research is to conceptually couple microalgae cultivation with an existing Ethiopian sugar factory, which has an annexed ethanol factory, so that the wastewater and the flue gas from the factories are used as nutrient and $\mathrm{CO}_{2}$ sources for the microalgae growth. The study explores a future possible microalgal cultivation integration approach with sugar and ethanol production factories by following a case study approach which uses the wastes and by-products as inexpensive $\mathrm{CO}_{2}$ and nutrient sources for the growth of the algae. The primary goal was to produce biodiesel and biogas using this integrated process. Bio-fertilizer is also considered as a by-product of the integrated process. The integrated process was evaluated with regard to product output, energy requirement, and energy output. Likewise, the effect of several factors, such as oil content in the microalgae and the nitrogen content in the wastes on the production of biodiesel, were investigated.

\section{Methods}

\section{Process design and integration}

In the present study, a case study approach was followed. The Metahara sugarcane-processing factory from the southeastern part of Ethiopia was selected (Fig. 1). The key process parameters for the factory are shown in Table 1 . The process design is based on the total nitrogen (TN) and total phosphorus (TP) contents in the wastewater effluent from the sugar mill (Table 2) and the vinasse from the annexed ethanol production plant of the factory (Table 3). Photoautotrophic cultivation of the microalgae in ponds was assumed where the wastewater and the recycled nutrients from an anaerobic digestion step could be used as nutrient sources and the flue gas from the factory as a $\mathrm{CO}_{2}$ source. It was supposed that the amount of $\mathrm{CO}_{2}$ required would be based on the amount of nutrients in the waste effluents (the wastewater and the vinasse). Hence, the nutrients should be considered as the limiting resources. Detail design equations are given in Appendix A.

\section{Microalgal biomass production in the ponds}

There are several microalgal strains such as Chlorella $s p$. and Scenedesmus sp. with a good potential for biofuel production $[17,18]$. When taking this into account, the present study was not limited to only a specific strain; a generic approach based upon modeling without experimental data of a specific strain was used.

Considering the fact that algal biomass contains about $50 \%$ of carbon, $\mathrm{C}, 1-10 \%$ of nitrogen, $\mathrm{N}$, and less than $1 \%$ of phosphorus, $\mathrm{P}$ [19], the microalgae used in this study were supposed to have the elemental formula of $\left(\mathrm{C}_{106} \mathrm{H}_{181} \mathrm{O}_{45} \mathrm{~N}_{15} \mathrm{P}\right)[7,18]$. This composition was used to evaluate the potential of the wastes from the factory to support the microalgae growth. The microalgae were assumed to be cultivated photoautotrophically in open ponds using sunlight as the source of energy. The wastewater from the sugar mill exiting from different sections including the milling house, the boiling house, the factory laboratory, and the factory garage (Table 2) could be used as the source of nutrients after its primary treatment in the respective primary treatment plant (Table 4). In addition to the wastewater, the vinasse from the distillation unit of the annexed ethanol production plant could be used as a source of nutrients for the algae in the ponds. This might be done by recovering the nutrients after the anaerobic digestion of the vinasse in an anaerobic digester $(\mathrm{AD})$ together with other inputs. The reduction factors in the primary treatment plant are shown in Table A.1 (Appendix B). The primary treatment plant would help to reduce the wastewater so that the photosynthesis process in the pond could increase. The $\mathrm{CO}_{2}$ required for the growth of the microalgae would be supplied from the flue gases coming out from either the boiler of the sugar factory or the fermenter of the ethanol factory. The starter culture microalgal strains were supposed to be developed in photobioreactors (PBRs) to reduce contamination. The algal broth from the PBRs would then be added to the cultivation 


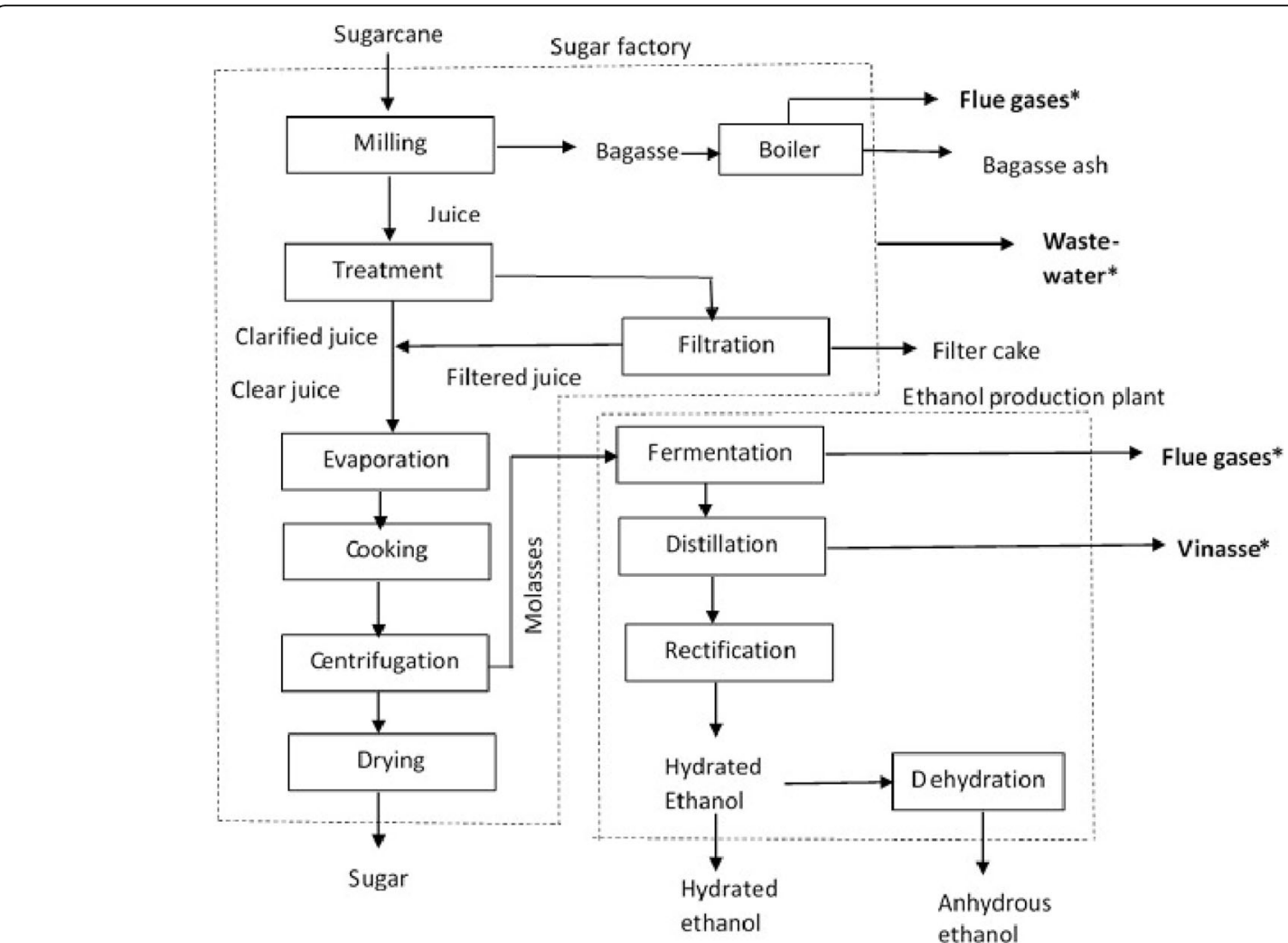

Fig. 1 Sugar and ethanol production flow chart for the Metahara Sugar Factory (*the wastewater from the sugar mill, the flue gases, and the vinasse would be used to support the algae growth)

ponds on one side of the paddle wheel and should be circulated along the ponds. After growth and circulation, the algal biomass should be collected at the harvest point on the other side of the paddle wheel. The key assumptions used in the cultivation model are shown in Table 5 .

\section{Harvesting of the biomass}

The biomass from the ponds was assumed to pass through three harvesting units: settling, dissolved air floatation (DAF), and centrifugation. It was assumed that dilute algal biomass from the pond with a concentration

Table 1 Main process parameters for the factory used in the modelling

\begin{tabular}{|c|c|c|}
\hline Parameters & Value & References \\
\hline Sugarcane crop area (ha) & 10230 & Factory data \\
\hline Cane production (tons/ha/year) & 144 & Factory data \\
\hline Days of operation of the factory & 250 & Factory data \\
\hline Mill Capacity (tons/day) & 5000 & Factory process data \\
\hline Bagasse production, dry wt. (\% on cane) & $14 \%$ & Factory process data \\
\hline Excess bagasse (\% total bagasse) & $15.50 \%(14-17 \%)$ & Factory process data \\
\hline Heat content of bagasse (BTU/lb dry wt.) & 7893 & [14] \\
\hline Mass of flue gasses produced (dry wt.) (kg of flue gases $/ \mathrm{kg}$ of bagasse) & 7.41 & [15] \\
\hline $\mathrm{CO}_{2}$ produced, ( $\mathrm{kg}$ of $\mathrm{CO}_{2} / \mathrm{kg}$ bagasse dry) & 1.72 & [15] \\
\hline Surplus water produced at mill (\% on cane) & $20 \%$ & Factory process data \\
\hline Molasses produced (\% on cane) & $3.20 \%$ & Factory process data \\
\hline Ethanol produced (m³/tons molasses processed) & 0.23 & Factory process data \\
\hline $\mathrm{CO}_{2}$ produced from EtoH plant, (tons $\mathrm{CO}_{2} /$ tons of molasses used) & 0.21 & Factory process data \\
\hline Vinasse produced, ( $\mathrm{m}^{3}$ of vinasse/ tons of molasses processed ) & 2.30 & Factory process data \\
\hline
\end{tabular}


Table 2 Characteristics of the wastewater effluent from Metahara sugar factory, Addis Ababa, Ethiopia

\begin{tabular}{|c|c|}
\hline Parameter & Value $^{a}$ \\
\hline Biological oxygen demand, $\mathrm{BOD}_{5}\left(\mathrm{mg} / \mathrm{L}_{\mathrm{mw}}\right)$ & $1200 \pm 163.30$ \\
\hline Chemical oxygen demand, COD (mg/Lww) & $2200 \pm 108.01$ \\
\hline Total nitrogen, TN (mg/Lww) & $15 \pm 0.41$ \\
\hline Total phosphorus, TP (mg/Lmw) & $10 \pm 0.33$ \\
\hline Total suspended solids, TSS (mg/Lww) & $362 \pm 2.16$ \\
\hline Oil and grease $\left(\mathrm{mg} / \mathrm{L}_{w w}\right)$ & $60 \pm 4.67$ \\
\hline Total dissolved solids, TDS (mg/Lww) & $210 \pm 3.74$ \\
\hline $\mathrm{pH}$ & $6.60 \pm 0.65$ \\
\hline Temperature $\left({ }^{\circ} \mathrm{C}\right)$ & $29.70 \pm 0.65$ \\
\hline Average flow ( $\mathrm{m}^{3} /$ day) & $1074 \pm 6.89$ \\
\hline
\end{tabular}

${ }^{a}$ Each value indicates the average value \pm standard deviation estimated from wastewater characteristics determined in three milling seasons

of $0.50 \mathrm{~g} / \mathrm{L}(0.05 \%)$ would be directed to the settling process with an algal removal efficiency of $95 \%$ where it should be concentrated to $10 \mathrm{~g} / \mathrm{L}$ ( $1 \%$ concentration) via auto-flocculation [18, 30]. Here, no electricity demand was accounted for mixing during coagulation. The settled solids would then be sent to the DAF process which again would have an assumed capture efficiency of $90 \%$ with $60 \mathrm{~g} / \mathrm{L}$ ( $6 \%$ solids concentration) as an output [31]. It was assumed that power consumption of $0.10 \mathrm{kWh} /$ $\mathrm{m}^{3}$ would be used in the DAF [32]. For centrifugation, self-cleaning disc stack centrifuges with an energy

Table 3 Assumed characteristics of molasses' vinasse from Metahara Ethanol production plant, Ethiopia [16]

\begin{tabular}{|c|c|}
\hline Parameter & Value \\
\hline $\mathrm{pH}$ & $4.10-5.00$ \\
\hline Temperature $\left({ }^{\circ} \mathrm{C}\right)$ & $80-100$ \\
\hline $\mathrm{BOD}\left(\mathrm{mg} \mathrm{O}_{2} / \mathrm{L}\right)$ & 25,000 \\
\hline $\mathrm{COD}\left(\mathrm{mg} \mathrm{O}_{2} / \mathrm{L}\right)$ & 65,000 (range $50,000-150,000$ ) \\
\hline Total solids (mg/L) & 81,500 \\
\hline Free solids (mg/L) & 60,000 \\
\hline Fixed solids (mg/L) & 21,500 \\
\hline TN (mg N/L) & $1000(450-1610)$ \\
\hline $\mathrm{TP}\left(\mathrm{mg} \mathrm{P} \mathrm{P}_{2} \mathrm{O}_{5} / \mathrm{L}\right)$ & $150(100-290)$ \\
\hline Potassium (mg K $\mathrm{K}_{2} \mathrm{O} / \mathrm{L}$ ) & $3740-7830$ \\
\hline Calcium (mg CaO/L) & $450-5180$ \\
\hline Magnesium (mg MgO/L) & $420-1520$ \\
\hline Sulphate $\left(\mathrm{mg} \mathrm{SO}_{4} / \mathrm{L}\right)$ & 6400 \\
\hline Carbon (mg C/L) & $11200-22,900$ \\
\hline $\mathrm{C} / \mathrm{N}$ ratio (mass ratio) & $16-16.27$ \\
\hline Organic material (mg/L) & 63,400 \\
\hline Reducing substances (mg/L) & 9500 \\
\hline Total vinasse flow rate $\left(\mathrm{m}^{3} / \text { day }\right)^{a}$ & 396 \\
\hline
\end{tabular}

${ }^{\mathrm{a}}$ Flow rate of the vinasse was estimated based on data from Table 1
Table 4 Estimated composition of effluent and sludge (bottom product) after primary treatment

\begin{tabular}{|c|c|c|}
\hline \multirow[t]{2}{*}{ Parameter } & \multicolumn{2}{|l|}{ Values $^{a}$} \\
\hline & Effluent & $\overline{\text { Sludge }}$ \\
\hline $\mathrm{BOD}_{5}\left(\mathrm{mg} / \mathrm{L}_{w w}\right)$ & 828 & 372 \\
\hline $\operatorname{COD}\left(\mathrm{mg} / \mathrm{L}_{\mathrm{w}}\right)$ & 1540 & 660 \\
\hline $\mathrm{TN}\left(\mathrm{mg} / \mathrm{L}_{w w}\right)$ & 12 & 3 \\
\hline TP (mg/Lww) & 7.4 & 2.6 \\
\hline TSS (mg/Lmw) & 145 & 217 \\
\hline Oil and grease (mg/Lww) & 21 & 39 \\
\hline TDS (mg/Lww) & 78 & 132 \\
\hline Flow rate ( $\mathrm{m}^{3} /$ day) & 1042 & 32 \\
\hline
\end{tabular}

${ }^{a}$ The values are obtained after the wastewater from the sugar factory is

treated in the primary treatment plant

consumption of $5 \mathrm{kWh} / \mathrm{m}^{3}$ of water removed and $95 \%$ algae retention was assumed [21,33]. Here, the concentration of the culture would be increased to $250 \mathrm{~g} / \mathrm{L}$ (25\%) [34]. In all the steps of harvesting, the lost biomass was expected to be caught by a filter and forwarded to the AD. An electricity demand of $0.01 \mathrm{kWh} / \mathrm{kg}$ algae was accounted for the filtration process.

\section{Biofuel production}

There are different options for the production of a biofuel from algal biomass, as illustrated in Fig. 2. In the figure, the pathways used in this study are highlighted. The criteria to choose the best pathway to utilize the biomass depends on many factors including material and energy efficiency, availability of infrastructures, $\mathrm{CO}_{2}$ emissions, and other environmental issues. In the present study, microalgae with oil content of $30 \%$ are regarded to be used as a base value [8], and this shows that only $30 \%$ of the total biomass will be utilized if, for example, the microalgae are only used for biodiesel production. To be more efficient in material utilization, other strategies enabling a utilization of the lipid-extracted algae (LEA) need to be employed. In this regard, simulteneous production of biodiesel and biogas has been found important as it is both material and energy efficient (which is highlighted in the figure in blue and orange colors) [7, 8]. Hence, biomass is assumed to be utilized for biofuel production via a biodiesel-biogas production pathway.

\section{Biodiesel production}

The biodiesel production should involve cell disruption, extraction, and transesterification of the oil to biodiesel.

\section{Cell disruption}

In the cell disruption unit, the algal biomass needs to be treated using an appropriate technology to increase the recovery of intracellular products during wet extraction. For the present work, high-pressure homogenization was 
Table 5 General assumptions for the microalgae cultivation

\begin{tabular}{|c|c|c|}
\hline Parameter/description & Value & References \\
\hline Assumed depth of pond (m) & 0.30 & [8] \\
\hline Assumed dimensions of a pond (m) & $\begin{array}{l}10,100 \text {, and } 0.30 \text { for width, length, and depth, } \\
\text { respectively }\end{array}$ & {$[8,20]$} \\
\hline Fraction of area occupied by the PBRs (\%) & 0.10 & [8] \\
\hline Temperature $\left({ }^{\circ} \mathrm{C}\right)$ & 29.70 & Characteristics of the wastewater \\
\hline $\mathrm{pH}$ & 6.60 & Characteristics of the wastewater \\
\hline Algae growth rate/productivity (g/m²/day) & 25 & {$[21,22]$} \\
\hline Mixing velocity in the pond $(\mathrm{cm} / \mathrm{s})$ & 25 & {$[8,23]$} \\
\hline Electricity demand by paddle wheel (kW/ha) & 2 & [8] \\
\hline Electricity demand to pump WW to pond (kWh/L) & $2.40 \times 10^{-5}$ & [23] \\
\hline $\begin{array}{l}\text { Electricity demand to pump from pond to bio- } \\
\text { flocculation }(\mathrm{kWh} / \mathrm{L})\end{array}$ & $4.80 \times 10^{-5}$ & \\
\hline Electricity demand for recycle pump (kWh/L) & $2.50 \times 10^{-5}$ & \\
\hline $\begin{array}{l}\text { Electricity consumption for flue gas injection }(\mathrm{kWh} / \mathrm{kg} \\
\left(\mathrm{CO}_{2}\right)\end{array}$ & $2.22 \times 10^{-2}$ & [24] \\
\hline$\%$ of flue gases captured & 90 & Estimated \\
\hline $\mathrm{CO}_{2}$ utilization (\% converted to algae) & 85 & {$[8,23]$} \\
\hline $\mathrm{CO}_{2}$ required for algal growth ( $\mathrm{g} \mathrm{CO}_{2} / \mathrm{g}$ algae dry) & 1.92 & From the microalgae composition \\
\hline TN required for algal growth (g N/g algae dry) & 0.09 & From the microalgae composition \\
\hline TP required for algal growth (g P/g algae dry) & $1.28 \times 10^{-2}$ & From the microalgae composition \\
\hline TN reduction (\%) & 95 & {$[25,26]$} \\
\hline TP reduction (\%) & 80 & [8] \\
\hline Water loss by evaporation (m/day) & $6.91 \times 10^{-3}$ & $\begin{array}{l}\text { Average evaporation rate data for } \\
\text { Metahara [27] }\end{array}$ \\
\hline Algae oil content (wt.\%) & 30 & [8], [28] \\
\hline Culture density (g/L) & $0.50(0.10-2)$ & {$[22,25]$} \\
\hline Ratio of total pond area to total facility foot print (\%) & 84 & [29] \\
\hline
\end{tabular}

considered. This method was selected because it is a well-established technology both on laboratory and industrial scale and has thus developed to one of the most commonly used methods [36]. The biomass with 25 wt.\% from the harvesting processes should be treated for cell disruption and lysis using pressure homogenization before forwarding it to extraction [18]. Energy consumption for pressure homogenization was assumed to be $0.20 \mathrm{kWh} / \mathrm{kg}$ of dry biomass and $90 \%$ efficiency, corresponding to a $25 \mathrm{wt} . \%$ input $[23,29]$. It is thought that the undisrupted algae in the homogenizer flow through the extraction (with no lipid recovery) to the digester with the residues.

\section{Lipid extraction}

Lipid extraction from algae is mostly performed either from wet algal paste or dry algal cake, with or without cell disruption [36]. In the present study, lipid extraction from wet algal paste using the solvent extraction technique with pretreatment or cell disruption is carried out. It is supposed that lipid extraction should be performed using ethanol. Ethanol should be used because of its polar nature enabling it to penetrate the polar cell membrane of the lipids so that more cell material could be made free and be extracted [37]. Moreover, ethanol has low toxicity and is available in the factory (ethanol is produced from cane molasses in Metahara factory). In some other extraction studies, a ratio of solvent to dry biomass of $5: 1(\mathrm{w} / \mathrm{w})$ was used, and the same ratio was assumed for the present study [29, 32]. A lipid recovery of up to $97 \%$ was reported in the literature [38]. However, for the present study, an $80 \%$ lipid recovery is considered as a base value. The lipid-rich solvent and the algae residue slurry are assumed to be separated through disk stack centrifugation [18]. The algal residues should then be forwarded to the AD for the biogas production, while the algae oil-solvent solution should be forwarded to a stripping column where the ethanol would be separated from the oil and recycled, leaving a $99.50 \%$ pure lipid stream $[7,18]$. The electricity requirement for the extraction step is assumed 


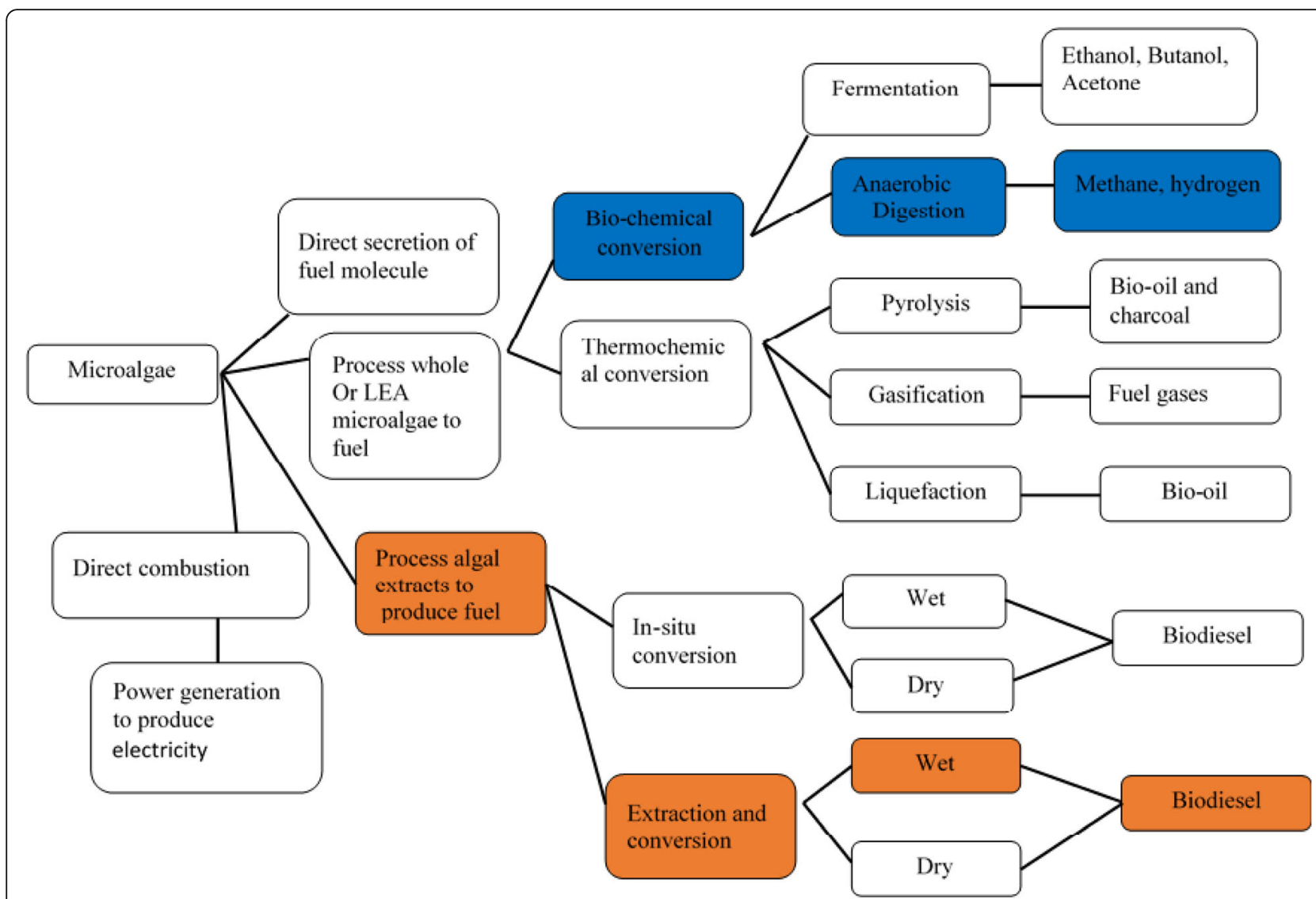

Fig. 2 Energy production from algae via different pathways, adapted from [5, 35] (the highlighted pathways are selected for the present study)

to be $0.28 \mathrm{kWh} / \mathrm{kg}$ per dry biomass $[23,29]$ while a thermal energy of $1.30 \mathrm{kWh} / \mathrm{kg}$ per dry biomass was accounted [21]. Solvent loss in circulation and lipid loss in the stripper are thought to be $5.20 \mathrm{~g}$ ethanol/ $\mathrm{kg}$ of oil and $5 \mathrm{wt} . \%$, respectively [7, 23, 32].

\section{Transesterification}

The extracted lipids would be transported and converted to biodiesel by transesterification using methanol in the presence of sodium hydroxide as a catalyst (1 wt.\%) [21]. The methanol-to-fatty acid mass ratio in the reactor was assumed to be 1:10 [21]. An 80\% (wt.\%) conversion rate of oil to biodiesel was assumed in the reactor as a base value $[39,40]$. There are some other studies which show that the free fatty acid content in the microalgae is very low, approximately $0.05 \%$ [40]. When taking this into account, a pretreatment step would not be necessary in the present study. The glycerol formed during transesterification was thought to be separated in a decanter with a purity of $85 \%$ glycerol and $15 \%$ methanol (wt.\%) [7] and would then be forwarded to the AD. It was assumed that $0.1 \mathrm{~kg}$ glycerol would be formed per kilogram of biodiesel [40]. The unreacted methanol was assumed to be recovered via distillation and recycled back to the reactor. The final purity of the fatty acid methyl ester (FAME) was regarded as 96.50\% (wt.\%). The contents of water, glycerol, and methanol in the FAME were expected to be 0.50 , 0.24 , and $0.20 \mathrm{wt} . \%$, respectively [7, 41]. Electrical and thermal energy requirements for the transesterification were expected to be $3.80 \times 10^{-4}$ and $0.68 \mathrm{kWh} / \mathrm{kg}$ of converted oil, respectively [21]. The density and energy content of the biodiesel were accounted to be $900 \mathrm{~kg} / \mathrm{m}^{3}$ and $42 \mathrm{MJ} / \mathrm{kg}$, respectively [21].

\section{Anaerobic digestion/biogas production}

In the biogas production model, it is assumed that the inflows to the $\mathrm{AD}$ are derived from five process steps. These include the vinasse, a by-product in ethanol production; the primary sludge from the wastewater primary treatment stage; the algae residues (lipid-extracted algae (LEA and the undisrupted algae) from the oil extraction step; the filtered algae in the harvesting section; and crude glycerol, a by-product from the transesterification step in the biodiesel production. 
The vinasse from the ethanol production factory was one of the components with a high mass flow rate (Table 3). Considering the molasses-based distillery effluent, vinasse, as the main component in the anaerobic digestion, the following four reactor configurations were implemented on a commercial scale: a continuous stirred-tank reactor (CSTR), an upflow anaerobic sludge blanket (UASB) reactor, a fixed film/media digester (or anaerobic filter, AF), and a thermophilic digester [42, 43]. The most successful configurations today are the UASB and CSTR reactors [43, 44]. The UASB reactors are used for the treatment of a wide range of industrial wastewaters (from low-to-high-strength wastewater) including vinasse $[42,45,46]$. UASB reactors are being encouraged because of their several advantages including plain design, uncomplicated construction and maintenance, low construction and operating costs, low sludge production, robustness in terms of chemical oxygen demand (COD) removal efficiency and wide applicability, less $\mathrm{CO}_{2}$ emissions due to less energy requirement, as well as quick biomass recovery [47].

In the present study, the vinasse (see Table 3) is characterized by a high total solid and high COD content. Glycerol, high-strength wastewater (with a high concentration of CODs), lipids, and some fatty acids would be added along with the vinasse which are characterized by a high solid content. In a UASB reactor, the hydraulic retention and solids retention time are not the same, and an uncoupling of the substrate from the hydraulic system is observed. Hence, operating substrates with a high total solid content in the UASB possibly damages the granular structure. As all those compounds are complex molecules, they also might adversely affect the performance of the UASB reactor [48]. Furthermore, the phenolic compounds in the vinasse might contribute to the color of the vinasse and make biodegradability to be difficult in the UASB [49]. On the other hand, complex organic materials with high solid content can better be degraded by means of CSTR reactors. Using municipal organic waste, which is characterized by a high total solid content $\left(171 \mathrm{~kg} / \mathrm{m}^{3}\right)$ and a high COD $(235 \mathrm{~kg}$ $\mathrm{COD} / \mathrm{m}^{3}$ ) as a substrate, allows a degradation of $68 \%$ COD to be achieved as was reported for a CSTR [50]. González et al. [51] recommended that co-digestion of vinasse with press mud using a CSTR reactor would be an excellent option for the treatment of streams of the alcohol sugar industry. Thus, a CSTR reactor was supposed to be used for the present study. In such a CSTR, a $65 \%$ COD removal and $0.29 \mathrm{~m}^{3} / \mathrm{kg}$ COD removed is expected for the vinasse.

\section{Inputs to the $A D$}

In the $\mathrm{AD}$, the production of biogas was modeled based upon the volatile solids (VS), total solids (TS), methane yield per gram of volatile solids (g-VS), chemical oxygen demand (COD), and percent methane $\left(\mathrm{CH}_{4}\right)$ content in the biogas. The total amount of $\mathrm{CH}_{4}$ produced in the AD was estimated using the $\mathrm{CH}_{4}$ yield for each component transferred to the AD.

One of the inputs, which would directly go to the $\mathrm{AD}$, was the algal residue (LEA and undisrupted algae in the disruption unit) from the extraction step. The solid concentration of algal biomass from the centrifugation step would be $25 \%$ as explained before. As the lipid content of the algae was considered to be $30 \%$, and from $24 \%$ of it would be extracted in the extraction unit, the solid concentration entering in the digester could be calculated using the mass flows of carbon, hydrogen, oxygen, nitrogen, and phosphorous from the oil extraction [7]. By assuming that TN and TP would not be affected in the extraction step but the carbon, the mass of the LEA was estimated by subtracting the total carbon extracted from the total algal biomass. It was assumed that the pretreatment step for the biomass, pressure homogenization, would help to increase the $\mathrm{CH}_{4}$ yield by $20 \%$ in the $\mathrm{AD}$ [7]. The whole biomass and the LEA were characterized to contain $0.73 \mathrm{~g}-\mathrm{VS} / \mathrm{g}$ TS and $0.63 \mathrm{~g}-\mathrm{VS} / \mathrm{g}$ TS, respectively [7]. Likewise, a biogas yield of $0.43 \mathrm{~L}$ $\mathrm{CH}_{4}$ /g-VS for the pretreated algae was supposed.

The primary sludge (Table 4) that contains grease, a carbon-containing component, which is removed during the primary wastewater treatment, was the second input to the AD. Broberg et al. [7] in their modeling considered that such grease consists of oleic acid with the empirical formula $\mathrm{C}_{18} \mathrm{H}_{34} \mathrm{O}_{2}$ and a density of $0.90 \mathrm{~g} / \mathrm{mL}$, and also a fatty acid found in sources of animals as well as vegetables. In this study, this assumption was applied. The amount of the grease could be estimated using a component concentration and the wastewater flow. It was assumed that the primary sludge contains $5.5 \%$ solid concentration (wt.\%) $[7,8,18]$, with a sludge flow rate of $32 \mathrm{~m}^{3} /$ day. For the given flow rate, an average density for water and grease (of $0.99 \mathrm{~g} / \mathrm{mL}$ ) was assumed. In this case, the amount of solid (grease) was obtained to be as high as $1750 \mathrm{~kg} /$ day, which corresponds to the amount of total solids, TS. Of the total solids, typically about $98.50 \%$ are volatile (VS content of oleic acid) [52] and would be broken down in the AD [8]. The methane yield for oleic acid was assumed to be $0.32 \mathrm{~L} \mathrm{CH}_{4} / \mathrm{g}$-VS [53].

The third input was the crude glycerol which was assumed to consist of $85 \%$ glycerol and 15\% methanol [7]. The VS content in glycerol amounted to $0.85 \mathrm{~g}-\mathrm{VS} / \mathrm{g}$ glycerol $[7,41]$ and $99 \%$ of methanol was also assumed to be volatile [7, 54]. A methane yield of $0.43 \mathrm{~L} \mathrm{CH}_{4} / \mathrm{g}-\mathrm{VS}$ and $0.53 \mathrm{~L} \mathrm{CH}_{4} / \mathrm{g}$-VS were estimated for glycerol and methanol, respectively $[7,55]$. In anaerobic co-digestion of mixtures, it is recommended that the amount of 
glycerol should not exceed 1\% (v/v) [56], and thus, this criteria was satisfied in the present study.

The last inflow to the digester would be the vinasse from the ethanol production factory (Table 3). All the vinasse would go to the $\mathrm{AD}$ to be anaerobically digested together with the other inflows. The residue from the digester can be used for irrigation of either sugarcane or for the cultivation of microalgae in the pond. In this study, the supernatant was assumed to be recycled to the pond so that it would provide the microalgae with nutrients in addition to the wastewater from the sugar factory while the solid by-product would be used as a bio-fertilizer for the sugar cultivation. The COD, TN, and TP reduction factors in the digester are shown in Table A.2 (Appendix B). The process energy per volume of $\mathrm{CH}_{4}$ produced or nutrient recovered depends on the digestion time and digester size. Digesters for wastewater treatment (WWT) applications are typically designed for a 20-50-day solid retention time [23, 57]. In the present study, for the AD system, a power consumption of 0.22 $\mathrm{kWh}$ thermal $/ \mathrm{kg}$ TS and $0.09 \mathrm{kWh}$ electrical $/ \mathrm{kg}$ TS with a solid retention time of 40 days was presumed [21, 23, $29,58]$. This assumption included the additional electric power, used by a disc stack centrifuge, for concentrating solids from the digestate. Then, the digestate was supposed to be dried and used as a fertilizer. The solids concentration in the digester would be obtained from the total mass flow of solids transferred. It was supposed that a biogas with a methane content of $84 \%$ and a balance $\mathrm{CO}_{2}$ would be produced from the $\mathrm{AD}$ [45].

\section{Biogas upgrading}

Biogas is commonly used to generate electricity and/or heat. Biogas can also be used as transportation fuel after purifying it into biomethane. Metahara sugary factory produces bioethanol to be used as transportation fuel by blending it with petro-diesel. Along with this bioethanol, in the present study, it is intended to deliver the biogas and the biodiesel, which would be produced in the coupled process, to the energy grid of the country and subsequently to be used as transportation fuel. The content of $\mathrm{CH}_{4}$ in the gas needs to be greater than $95 \%$ (96\% was assumed in the present study) for the gas to be used as transportation fuel [7]. Thus, the gas needs to be upgraded using an appropriate technology. Four types of technologies are commonly employed for the removal of $\mathrm{CO}_{2}, \mathrm{H}_{2} \mathrm{~S}$, and other impurities: membrane separation, adsorption, cryogenic distillation, and absorption. Absorption processes are suitable for large-scale processing units. Water scrubbing is common for biogas production. In this study, water scrubbing was used. The principle of a water scrubber is that $\mathrm{CO}_{2}$ is highly soluble in water, whereas $\mathrm{CH}_{4}$ is not. The gas is fed at the bottom of the scrubber tower, while the water enters the tower from the top so that the $\mathrm{CO}_{2}$ is dissolved in the water and the gas rich in $\mathrm{CH}_{4}$ comes out from the top. In the reverse absorption (the stripper tower), the $\mathrm{CO}_{2}$ desorbs from the $\mathrm{CO}_{2}$-rich water. The $\mathrm{CO}_{2}$ desorbs from the water as the solvent travels down the tower. It was assumed that $0.50 \%$ of the $\mathrm{CH}_{4}$ would be lost during the upgrading process [7]. The $\mathrm{CO}_{2}$ gas from desorption step can be used as a carbon source in the pond, depending on mass balance. It was presumed that the energy demand of the water scrubber has to be $0.17 \mathrm{kWh} /$ $\mathrm{m}^{3}$ biogas and the temperature in the scrubber process $20^{\circ} \mathrm{C}$ [7]. Considering that the energy density of $\mathrm{CH}_{4}$ is $39.90 \mathrm{MJ} / \mathrm{m}^{3}\left(11.20 \mathrm{kWh} / \mathrm{m}^{3}\right)$, the energy content of the biogas could be determined [59].

\section{Nutrient recovery}

It was thought that the concentration of $\mathrm{TN}$ and $\mathrm{TP}$ after digestion could be reduced by $16 \%$ and $21 \%$, respectively [23]. Of the inflows to the $\mathrm{AD}$, only the vinasse and the algae residue were assumed to contain nitrogen and phosphorus and thus used to supply the pond. The output from the AD would be split into two fractions, namely the supernatant and the solid digestate, and it would then enter the pond to provide the microalgae with nitrogen and phosphorus, while the digester solid would be used as a bio-fertilizer after treatment. It was expected that $25 \%$ of the TN would reside in the sludge and $75 \%$ would reside in the supernatant, while the TP would be split 50/50 between the solid and liquid phases [23]. It was also assumed that there would be $5 \%$ and 20\% loss for TN and TP, respectively, as was also presumed before for the wastewater.

\section{Evaluation of the integrated process}

The integrated process was evaluated with regard to product outputs and energy inputs and outputs using a spreadsheet.

\section{Sensitivity analysis}

Sensitivity analysis is important to determine which parameters potentially affect the response variable [18]. In the present study, four parameters viz. oil content of the microalgae, the nitrogen content in the vinasse from the ethanol factory, the extraction efficiency, and the transesterification efficiency of the crude oil to biodiesel were selected, and it was studied how their change in value affects the biodiesel yield in the integrated process. Low, base, and high values were assigned for each parameter and the sensitivity of the biodiesel yield to the change of the parameters from the base value was investigated.

The oil content of microalgae may vary depending on the type of the microalgae strain and its cultivation conditions [60]. The oil content in microalgae can reach $80 \%$ and even more, while a $20-50 \%$ oil content is 
common [3], which indicates that the microalgae have great potential to be a future renewable biofuel resource. As mentioned in Section 2.1.3, for the present study, a realistic value of $30 \%$ was considered as a base value. For the sensitivity study, an oil content of $20 \%$ and $40 \%$ was used as low and high values, respectively.

The biomass production in the ponds depends of their nutrient supply, and the biomass production in turn affects the biodiesel production. Nitrogen is an essential constituent of all structural and functional proteins in algal cells accounting for about $7-10 \%$ of the cell dry weight (DCW) [61]. Likewise, the sensitivity of the biodiesel to a change in the nitrogen content of vinasse, the main nitrogen source, was studied. From the mass balance equations, the anaerobically digested vinasse can provide the microalgae with 99 tons/year of nitrogen. Base values of 70 and 120 tons/year were used as low and high values, respectively.

The extraction efficiency of oil from the microalgae is also an important factor, which affects the production of biodiesel. Depending on the type of the solvent used and the microalgae species, a recovery of $>95 \%$ of the lipids is possible. An extraction efficiency of up to $98 \%$ was reported in the literature [38]. For the present study, 60, 80 , and $97 \%$ extraction efficiencies were assumed as low, base, and high values, respectively, for the sensitivity analysis.

The biodiesel production is also directly proportional to the transesterification efficiency of the crude oil. For the sensitivity analysis of the present study, a 70, 80, and $90 \%$ transesterification efficiency of oil in the reactor was considered [39, 40].

\section{Results and discussions}

\section{Process design and integration}

The integrated process is shown in Fig. 3. Likewise, the material flow in the integrated process is presented in Fig A-1, Fig A-2, and Fig A-3 (Appendix C). The wastewater (after primary treatment) and the flue gas from the sugar factory are used as nutrients and $\mathrm{CO}_{2}$ sources for the growth of the microalgae in the ponds. The selected microalgae are grown in the PBRs before they have been transferred to the ponds. The algae biomass cultivated in the ponds is harvested in a series of

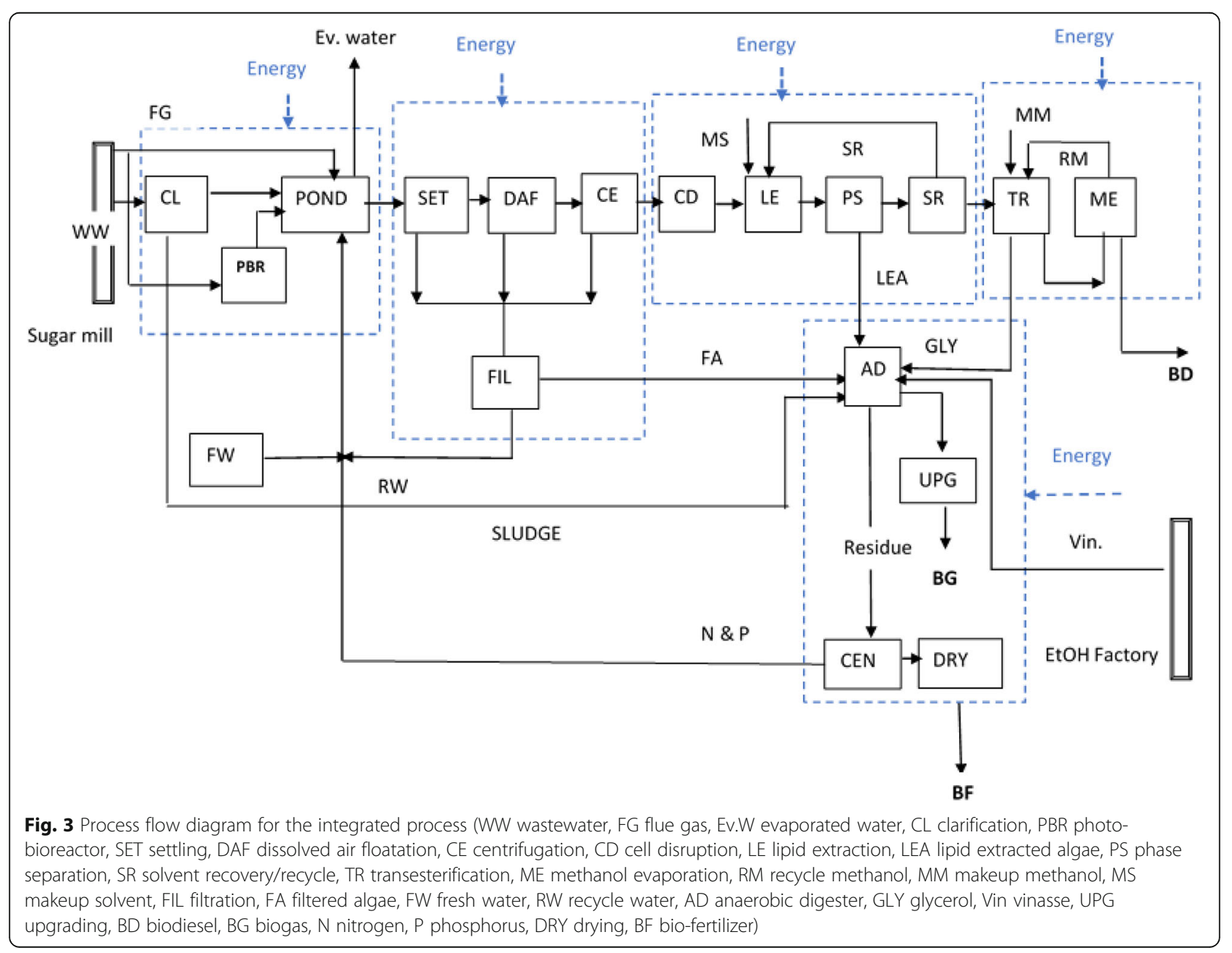


harvesting units (settling, DAF, and centrifugation). The unrecovered biomass formed due to the inefficiencies of the harvesting units is recovered using the filtration unit. The algal biomass from the last harvesting unit, the centrifugation, is transferred to the oil extraction unit after a pretreatment in the cell disruption unit. The oil produced in the extraction unit is transferred to the transesterification unit where the biodiesel is produced. The glycerol, the by-product in the transesterification unit; the LEA and the undisrupted algae from the extraction unit; the filtered algae from the filtration unit; the sludge from the primary treatment plant; and the vinasse, the by-product, from the ethanol production plant, are digested in the $\mathrm{AD}$ to produce the biogas. The bottom product from the AD is separated into two products: the supernatant and the bottom product using centrifugation. The supernatant is recycled and fed to the ponds where it is used as a source of nutrient along with the wastewater from the sugar factory. The bottom product is used for the production of the bio-fertilizer. The biodiesel (BD), biogas (BG), and bio-fertilizer (BF) are the three main products of the integrated process.

\section{Cultivation and harvesting of the microalgae}

The results from the cultivation and harvesting models are shown in Table 6. The wastewater effluent from the sugar factory would be reduced in the primary treatment plant. As shown in Table 4, this operation could help to treat the wastewater before going to the ponds; the solids, the COD, and the BOD are reduced in the wastewater, and this possibly could increase the photosynthesis efficiency of the algae in the ponds which in turn increases the algal biomass production in the ponds.
The total algal biomass production in the ponds was found to be 1412 tons/year. As per the assumptions considered in the present study, this biomass would be obtained by using photoautotrophic cultivation in an open system, by assuming a real value of $25 \mathrm{~g} / \mathrm{m}^{2} /$ day for open pond productivity. Literature review reveals that due to their higher surface-to-volume (S/V) ratio, PBRs can help to achieve higher volumetric productivities and cell concentrations [62, 63]. Hence, if PBRs have been assumed for the cultivation of algae instead of using open ponds, the productivity would have increased, and more biomass could have been obtained. In addition to this, closed systems are preferred to open ponds because the contamination of algae is reduced [64]. However, due to their low investment and maintenance costs, which also results in lower production costs $[65,66]$, open pond systems are the most used systems in microalgae cultivation. These ponds can be constructed on the degraded lands [3] without competing with fertile land used for the cultivation of the sugar cane in the case of the present study. These advantages along with their simple design, scalability, and low energy input, makes the open systems suitable to be possibly implemented for the realization of the proposed idea. Due to the inefficiencies of the harvesting operations, 265.10 tons/year of algal biomass remains unrecovered and overflown with the water. The filtration unit would be used to solve this problem. The algal concentration in the pond is low $(0.50 \mathrm{~g} / \mathrm{L})$. Harvesting such dilute microalgal suspension to achieve the final concentration of $250 \mathrm{~g} / \mathrm{L}$ is highly energy and capital intensive. In another study, it has been reported that harvesting accounts for $20-30 \%$ of the overall production costs of microalgal biofuels [67].

Table 6 Outputs from the cultivation and harvesting models

\begin{tabular}{|c|c|c|c|c|}
\hline \multirow[t]{2}{*}{ Parameters } & \multirow{2}{*}{$\begin{array}{l}\text { Cultivation } \\
\text { Pond }\end{array}$} & \multicolumn{3}{|l|}{ Harvesting } \\
\hline & & Bio-flocculation & DAF & Centrifugation \\
\hline Biomass concentration (g/L) & 0.50 & 10 & 60 & 250 \\
\hline Dry content of algae (tons/year) & 1412 & $1,341.40$ & $1,207.30$ & $1,146.90$ \\
\hline Area for cultivation land (ha) & $\sim 23$ & - & - & - \\
\hline Algae over flow (tons/year) & - & 70.60 & 134.10 & 60.40 \\
\hline Filtered algae (tons/year) & - & 70.60 & 134.10 & 60.40 \\
\hline Total water required in the pond $\left(\mathrm{m}^{3} /\right.$ year) & $2,824,000$ & - & - & - \\
\hline Total water feed to the ponds from the sugar factory $\left(\mathrm{m}^{3} /\right.$ year) & 260,500 & - & - & - \\
\hline Water loss from pond by evaporation ( $\mathrm{m}^{3} /$ year) & $390,841.60$ & - & - & - \\
\hline Treated water ( $\mathrm{m}^{3} /$ year) & - & $2,689,860$ & 114,019 & 15,533 \\
\hline Water recycle to the pond ( $\mathrm{m}^{3} /$ year) & $2,819,412$ & - & - & - \\
\hline Additional fresh water to pond ( $\mathrm{m}^{3} /$ year) & 134,930 & - & - & - \\
\hline Water with the microalgae $\left(\mathrm{m}^{3} /\right.$ year) & $2,824,000$ & 134,140 & 20,121 & 4587.60 \\
\hline Electricity demand (MWh/year) & 423.90 & - & 11.40 & 77.70 \\
\hline Electricity demand for filtration (MWh/year) & - & 0.70 & 1.30 & 0.60 \\
\hline
\end{tabular}


The lack of energy-efficient and cost-effective harvesting methodologies has been considered as the major problem for the economic production of algal biofuels [68]. In this regard, auto flocculation using gravity can decrease the energy consumption in the next harvesting operations. Taking this into account in the present study, the DAF and the centrifugation steps would be preceded by an auto flocculation step. In this auto flocculation step, the separation would be carried out by gravity, and no energy is required. As it is presented in Table $6,95 \%$ of the water in the algal broth would be removed during the auto flocculation step, which would decrease the energy consumption tremendously in the next harvesting units. Thus, it is considered that flocculation is an important step to decrease the biofuel production cost.

The N:P ratio in the wastewater was found to be 1.62 (Table 4). Literature review shows that for microalgae grown by utilizing all the nitrogen and phosphorus, the N:P ratio should be greater than $4: 1$ and less than 40:1 [7, 20]. In this regard, the primarily treated sugar factory wastewater is considered as nitrogen deficient. This deficiency can be compensated by makeup nutrients such as nitrates and ammonia. To avoid the use of such a makeup nutrient, it was assumed that the supernatant, the top product obtained by separating the sludge from the anaerobic digester into top and bottom products, would be recycled to the ponds and used as a source of nutrients. If no recycling is assumed, it would require to supply 7.91 tons/year of nitrogen as a makeup nutrient based on the amount of the total phosphorus contained in the wastewater. In this way, it would be possible to produce 121 tons/year of biomass in the ponds. However, as can be seen from Table 6, it was possible to produce a substantially increased (1412 tons/year) algal biomass by recycling the nutrients recovered in the anaerobic digestion unit without the use of any makeup nutrient (Fig. 4). The increased biomass production in turn could increase the oil and biofuel production capacity (Tables 7,8 , and 9). This shows that the usage of all the wastes in the process, in a zero-waste approach, could possibly increase the feasibility of the integrated process. Likewise, the results of the cultivation and the harvesting model demonstrate that when there is recycling, there will also be an increase of the cultivation area from 2 to 23 ha (Fig. 5) and an increase in energy requirements in parallel with the increase of biomass production.

\section{Oil extraction}

Based on the assumption considered in Section 2, the main results from the extraction model are given in Table 7. The model shows that the total recovered extracted oil entering the esterification reactor was found to be 235.36 tons/year with a thermal energy and electricity demand of 1341.95 and $284.91 \mathrm{MWh} /$ year, respectively. A high thermal energy demand was required as wet extraction was assumed. In wet extraction, the presence of water could be a problem because it can either promote the formation of emulsions in the presence of ruptured cells or participate in side reactions when present in the bulk solution. At the cellular level, intracellular water can be a barrier between the solvent and the solute.

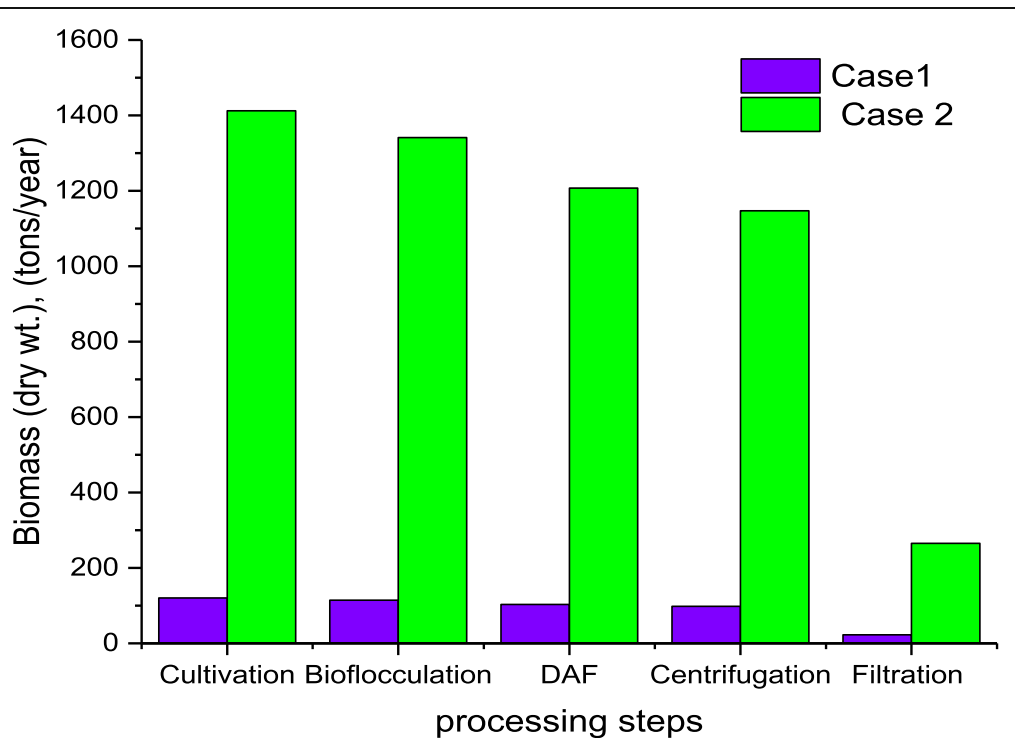

Fig. 4 Dry content of algae in the cultivation (ponds) and after harvesting (Case 1 when sugar mill WW is used as the only nutrient source with makeup nutrient and Case 2 when there is nutrient recovery from the AD) 
Table 7 Outputs from the extraction model

\begin{tabular}{ll}
\hline Parameter & Value \\
\hline Disrupted algae flow to extraction step (tons/year) & 1032.27 \\
Undisrupted flow to extraction step (tons/year) & 114.70 \\
Total recovered extracted oil entering to esterification reactor & 247.75 \\
(tons/year) & \\
Lipid lost (tons/year) & 12.39 \\
Oil going to transesterification (tons/year) & 235.36 \\
Ethanol required (tons/year) & 5161.35 \\
Make-up flow of ethanol (tons/year) & 1.29 \\
LEA to AD (tons/year) & 784.53 \\
Undisrupted algae to AD (tons/year) & 114.70 \\
Electricity demand for homogenizer (cell disruption) (MWh/ & 206.45 \\
year) & \\
Electricity demand for extraction (MWh/year) & 284.91 \\
Thermal energy for extraction (MWh/year) & 1341.95
\end{tabular}

Increasing the temperature and the pressure can reduce the problem but at the expense of a high energy input. To reduce the temperature and pressure requirements during extraction, cell disruption can be applied [62]. Thus, in the modeling, the pressure homogenization step was assumed to help reduce the high temperature and pressure demand. As it is evident in Table 7 , the cell disruption and extraction steps share $35 \%$ of the total energy demand in the whole integrated process; this accounts for the larger energy share next to the biogas production section which accounts for $53 \%$ of the total energy in the process.

Table 8 Outputs from the esterification model

\begin{tabular}{ll}
\hline Parameter & Value \\
\hline Lipid flow (tons/year) & 235.36 \\
Methanol flow (tons/year) & 23.54 \\
$\begin{array}{l}\text { Make-up flow methanol (tons/ } \\
\text { year) }\end{array}$ & 3.71 \\
Catalyst used (tons/year) & 1.88 \\
Biodiesel output (tons/year) & 188.29 \\
Energy of biodiesel (MWh/year) & 2197.34 \\
Purity of biodiesel (wt.\%) & $97 \%$ of 0.24\% glycerol, 0.2\% methanol, \\
& $0.0005 \%$ water, and the balance of \\
& other impurities \\
Glycerol output (tons/year) & 18.83 \\
Glycerol lost (tons/year) & 0.05 \\
Glycerol going to AD (tons/year) & 18.78 \\
Glycerol purity (wt.\%) & $85 \%$ glycerol, 15\% methanol \\
Electricity requirement (MWh/ & 0.07 \\
year) & \\
$\begin{array}{l}\text { Thermal energy requirement } \\
\text { (MWh/year) }\end{array}$ & 128.04 \\
\hline
\end{tabular}

Table 9 Mass flow into the AD and methane output

\begin{tabular}{|c|c|c|c|c|}
\hline Inputs & $\begin{array}{l}\text { TS (tons/year) } \\
\text { or COD } \\
\text { reduced (tons } \\
\mathrm{O}_{2} / \text { year) }\end{array}$ & $\begin{array}{l}\text { VS to TS } \\
\text { ratio (kg- } \\
\text { VS/kg TS) }\end{array}$ & $\begin{array}{l}\text { Methane yield }\left(\mathrm{m}^{3}\right. \\
\left.\mathrm{CH}_{4} / \mathrm{kg}-\mathrm{VS}\right) \mathrm{OR}\left(\mathrm{m}^{3}\right. \\
\mathrm{CH}_{4} / \mathrm{kg} \mathrm{COD} \\
\text { utilized) }\end{array}$ & $\begin{array}{l}\text { Total } \\
\text { methane } \\
\text { yield }\left(\mathrm{m}^{3} /\right. \\
\text { year) }\end{array}$ \\
\hline LEA & 784.53 & 0.63 & 0.43 & 212,530 \\
\hline $\begin{array}{l}\text { Unextracted } \\
\text { algae }\end{array}$ & 114.70 & 0.73 & 0.43 & 36,004 \\
\hline $\begin{array}{l}\text { Primary } \\
\text { sludge }\end{array}$ & 437.5 & 0.99 & 0.32 & 435,250 \\
\hline Glycerol & 18.83 & 0.85 & 0.43 & 6880 \\
\hline Methanol & 3.32 & 0.99 & 0.53 & 1740 \\
\hline Vinasse & 4182.8 & - & 0.29 & $1,213,010$ \\
\hline Total & & & & $1,905,414$ \\
\hline
\end{tabular}

\section{Biodiesel production/transesterification}

Based on the assumption shown in Section 2, the main results from the transesterification model are given in Table 8. The model result indicates that it is possible to produce 188.29 tons/year of biodiesel from 1412 tons/year of algal biomass produced in the ponds. The thermal energy demand for the biodiesel production was found to be 128.04 MWh/year, which is much lower than the thermal energy (1341.95 MWh/year) required in the extraction step. The energy content of the biodiesel was estimated to be 2197.34 MWh/year. The energy required for the biomass conversion to biodiesel is the total sum of the energy required in the cell disruption, cell extraction, and transesterification sections, which sums up to 1954.40 tons/year. A negative energy balance has been considered as the major bottleneck in the microalgae biomass extraction/conversion process [69]. As it was estimated in the present study, the

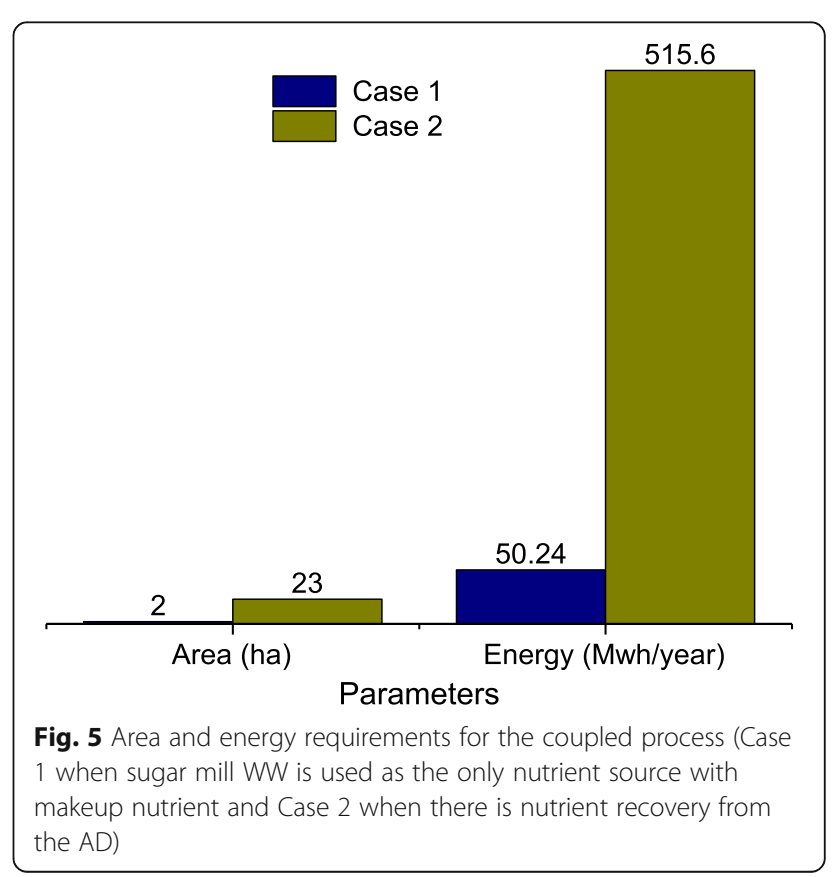


energy content of the biodiesel (output energy) was greater than the input energy, implying that the extraction/conversion process resulted in a positive energy balance. This might be attributed to both the homogenization step assumed to help reduce the high temperature and pressure demand and the high extraction and transesterification efficiencies expected in the process.

\section{Biogas production}

Based on the assumptions shown in Section 2, the main outputs from the biogas production and upgrading model are presented in Tables 9, 10, and 11. The results in Table 9 demonstrate that for 250 working days in a year, a total methane yield of $1,905,414 \mathrm{~m}^{3} /$ year $\quad\left(1,974,882 \mathrm{~m}^{3} /\right.$ year upgraded biogas) would be obtained. The total energy requirement for the biogas production and the upgrading unit operations was estimated to be $2796.55 \mathrm{MWh} /$ year. The total liquid influent to the AD is $432.52 \mathrm{~m}^{3} /$ day (which is the sum of vinasse, $396 \mathrm{~m}^{3} /$ day; sludge, $32 \mathrm{~m}^{3} /$ day; algae residue, $4.5 \mathrm{~m}^{3} /$ day; and crude glycerol, $0.019 \mathrm{~m}^{3} /$ day).

Total nitrogen content of the bio-fertilizer was estimated using the assumption that the digestate solid would contain $25 \%$ of the nitrogen contained in the solid digested algae residue and digested vinasse. Thus, it was found that the bio-fertilizer obtained by drying the digestate solid would contain 42.06 tons TN/year. Tables 10 and 11 show the output and input energies in the biogas production section. Energy requirements the integrated process is displayed in Fig A-4 (Appendix C). Equally, the energy requirements by percentage for each process step of the whole process are shown in Fig. 6.

\section{Sensitivity analysis}

In order to investigate how the biodiesel production responds to a change in oil content of the algae, the extraction efficiency, transesterification efficiency, and nitrogen content of the vinasse were studied and shown in Fig. 7. The result shows that the production of the biodiesel is most sensitive to a change in the oil content of the algae. Its value is reduced from 188 to 135 tons/ year (by 28\%) when the oil content in the microalgae lowers from $30 \%$ (base value) to $20 \%$. Likewise, it is increased by $25 \%$ when the oil content in the microalgae rises to a value of $40 \%$. The result also shows that the biodiesel production reduces by 28,25 , and $20 \%$, when the values of the nitrogen content in the vinasse, the

Table 10 Outputs from the water scrubber

\begin{tabular}{ll}
\hline Parameter & Value \\
\hline Upgraded biogas ( $\mathrm{m}^{3} /$ year) & $1,974,882$ \\
$\mathrm{CO}_{2}$ outflow/removed ( $\mathrm{m}^{3} /$ year) & 270,420 \\
Energy content of produced upgraded biogas (MWh/year) & $22,118.68$ \\
\hline
\end{tabular}

${ }^{a}$ Value is calculated for energy content of methane $\left(11.2 \mathrm{kWh} / \mathrm{m}^{3}\right)$
Table 11 Energy demand for biogas production and upgrading

\begin{tabular}{ll}
\hline Process step & Value \\
\hline $\begin{array}{l}\text { Electricity demand of anaerobic digester for mixing (MWh/ } \\
\text { year) }\end{array}$ & 685.82 \\
Thermal energy of anaerobic digester for heating (MWh/year) & 1775 \\
Electricity demand for water scrubber (MWh/year) & 335.73 \\
Total (MWh/year) & 2796.55 \\
\hline
\end{tabular}

esterification efficiency, and the extraction efficiency, respectively, are reduced by 29,25 , and $25 \%$ from their respective base values. On the other hand, the biodiesel production is increased by 20,23 , and $16 \%$ when the nitrogen content in the vinasse, the esterification efficiency, and the extraction efficiency are increased by 21 , 23 , and $21 \%$ from their base respective values.

The results show that all the investigated parameters are important and need to be considered in the production of biodiesel from microalgae. The nitrogen content in the vinasse depends on the composition of the vinasse which in turn may depend on several factors including the ethanol production process. The oil content of microalgae can possibly be improved by applying an algal strain modification strategy. The extraction efficiency could be improved by selecting a solvent with higher extraction efficiency and optimizing the operating parameters, whereas the esterification efficiency could be improved by decreasing the impurities in the crude oil.

\section{Conclusion}

The wastes from the factory have a high potential for production of microalgal biomass and microalgal biofuel, biodiesel, and biogas. Moreover, the process integration shows that another important product, bio-fertilizer, can be produced which can possibly make the synergy of the processes feasible. The result shows that the vinasse

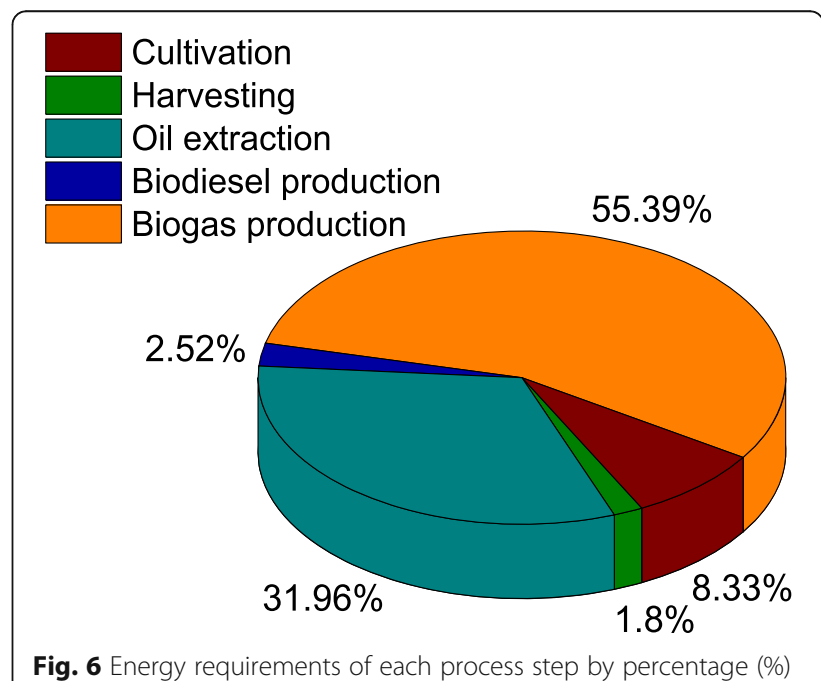


- East $n$ West

Oil content in algae (20\%:30\%:40\%)

$\mathrm{N}$-content in vinasse $(70: 99: 120)$

Ester. efficiency (60\%:80\%:98\%)

Ext.efficiency (60\%:80\%:97\%)

$\begin{array}{llllllll}120 & 140 & 160 & 180 & 200 & 220 & 240 & 260\end{array}$

Change to biodiesel production(tons/year)

Fig. 7 Biodiesel production sensitivity analysis

from the ethanol factory is the major nutrient source for the microalgae cultivation, as most of the nitrogen and phosphorus utilized by the algae in the pond is obtained from the vinasse after it is anaerobically digested in the AD. It was also found that the oil content of the algae, the nitrogen content of the wastes, and the extraction and transesterification efficiencies significantly affect the biodiesel production in the integrated process, implying that improving these parameters is significant in increasing the feasibility of the integrated process. The ratio of the output energy to the input energy is about 4.8 showing that the energy balance in the integrated process is positive. This in turn indicates that the process is energy efficient. The use of the vinasse as an input in the $\mathrm{AD}$ played a great role for the energy efficiency of the coupled process to be convincing. Since there are several factories and ongoing mega projects for processing of sugarcane in Ethiopia, such economic activities are necessary in order to improve the value of the process and reduce the environmental pollution. However, its provision requires further research work in different areas including the biology of microalgae, the technology for processing of microalgae, and the economic feasibility of the integrated process. The present study can play an important role in opening the way for such activities.

\section{Supplementary information}

Supplementary information accompanies this paper at https://doi.org/10. 1186/s13705-020-00262-5.

Additional file 1:. Appendices

\section{Abbreviations}

N: Nitrogen; TN: Total nitrogen; P: Phosphorus; TP: Total phosphorus; C: Carbon; PBR: Photo-bioreactor; DAF: Dissolved air floatation; AD: Anaerobic digester; LEA: Lipid-extracted algae; CSTR: Continuous stirred-tank reactor; UASB: Upflow anaerobic sludge blanket; AF: Anaerobic filter; OLR: Organic loading rate; COD: Chemical oxygen demand; BOD: Biological oxygen demand; VS: Volatile solids; TS: Total solids; TSS: Total suspended solids; TDS: Total dissolved solids; WW: Wastewater; WWT: Wastewater treatment; BD: Biodiesel; BG: Biogas; BF: Bio-fertilizer

\section{Acknowledgements}

The authors acknowledge the financial support from Debre Tabor University and Addis Ababa University.

Availability of supporting data

Supplementary material is accompanying the article.

Authors' contributions

The first author (DTZ) contributed to the conceptualization, data analysis, and drafting of the first version of the manuscript. The authors read and approved the final version of the manuscript.

\section{Authors' information}

DZ is Lecturer of Debre Tabor University, Debre Tabor, Ethiopia and PhD candidate in Process Engineering, School of Chemical and Bioengineering, Addis Ababa Institute of Technology, Addis Ababa University, Addis Ababa, Ethiopia. AA is Associate Professor and Dean of the School of Chemical and Bioengineering, Addis Ababa Institute of Technology, Addis Ababa University, Addis Ababa, Ethiopia

\section{Funding}

Not applicable

Ethics approval and consent to participate

Not applicable

\section{Consent for publication}

Not applicable

\section{Competing interests}

The authors declare that they have no competing interests.

Received: 30 August 2019 Accepted: 23 July 2020

Published online: 05 August 2020

References

1. Frank ED, Elgowainy A, Han J, Wang Z (2013) Life cycle comparison of hydrothermal liquefaction and lipid extraction pathways to renewable diesel from algae. Mitig Adapt Strateg Glob Chang 18(1):137-158

2. Bennion EP, Ginosar DM, Moses J, Agblevor F, Quinn JC (2015) Lifecycle assessment of microalgae to biofuel: comparison of thermochemical processing pathways. Appl Energy 154:1062-1071

3. Chisti Y (2007) Biodiesel from microalgae. Trends Biotechnol 25(3):294-306

4. D. López Barreiro, W. Prins, F. Ronsse, and W. Brilman, "Hydrothermal liquefaction (HTL) of microalgae for biofuel production: state of the art review and future prospects," Biomass Bioenergy, vol. 53, no. 0, pp. 113-127, 2013.

5. de Boer K, Moheimani NR, Borowitzka MA, Bahri PA (2012) Extraction and conversion pathways for microalgae to biodiesel: a review focused on energy consumption. J Appl Phycol 24(6):1681-1698 
6. Huang GH, Chen F, Wei D, Zhang XW, Chen G (2010) Biodiesel production by microalgal biotechnology. Appl Energy 87(1):38-46

7. R. Broberg, S, Andersson, V., \& Hackl, Integrated algae cultivation for biofuels production in industrial clusters., no. 1. 2011.

8. T. J. Lundquist, I. C. Woertz, N. W. T. Quinn, and J. R. Benemann, "A realistic technology and engineering assessment of algae biofuel production." Energy Biosciences Institute, University of California, Berkeley, California., California, 2010

9. Y. Grima EM, Belarbi EH, Fernández FA, Medina AR, Chisti N (2003) Optical and photoluminescent recovery of microalgal biomass and metabolites: process options and economics. Biotechnol Adv 20(7):495-515

10. Pragya N, Pandey KK, Sahoo PK (2013) A review on harvesting, oil extraction and biofuels production technologies from microalgae. Renew Sust Energ Rev 24:159-171

11. Fenton O, ÓhUallacháin D (2012) Agricultural nutrient surpluses as potential input sources to grow third generation biomass (microalgae): a review. Algal Res 1(1):49-56

12. O. Sialve B, Bernet N, Bernard N (2009) Anaerobic digestion of microalgae as a necessary step to make microalgal biodiesel sustainable. Biotechnol Adv 27(4):409-416

13. U. S. DOE, "National Algal Biofuels Technology Roadmap". U.S. Department of Energy, Office of Energy Efficiency and Renewable Energy, Biomass Program., 2010.

14. Tsai WT, Lee MK, Chang YM (2006) Fast pyrolysis of rice straw, sugarcane bagasse and coconut shell in an induction-heating reactor. J Anal Appl Pyrolysis 76(1-2):230-237

15. Mohamed Abdalla A, Hasan Hassan T, Mansour ME (2018) Performance of wet and dry bagasse combustion in Assalaya Sugar Factory - Sudan. Innov Energy Res 07(01):1-6

16. J. R. Moreira, "Water use and impacts due ethanol production in Brazil". National Reference Center on Biomass, Institute of Electrotechnology and Energy - CENBIO/IEE, University of São Paulo, São Paulo, Brazil, 2002

17. R. A. I. I. Abou-shanab, J. H. Hwang, Y. Cho, B. Min, and B. H. Jeon, "Characterization of microalgal species isolated from freshwater bodies as a potential source for biodiesel production," Appl Energy, vol. 88, no. 10, pp. 3300-3306, 2011.

18. Davis R, Aden A, Pienkos PT (2011) Techno-economic analysis of autotrophic microalgae for fuel production. Appl Energy 88(10):3524-3531

19. J. U. Grobbelaar, Handbook of microalgal culture. Applied Phycology and Biotechnology, Second Edition-Wiley-Blackwell. 2013.

20. Lardon L, Hélias A, Sialve B (2009) Life-cycle assessment of biodiesel production from microalgae. Environ Sci Technol 43(17):6475-6481

21. Delrue $F$ et al (2012) An economic, sustainability, and energetic model of biodiesel production from microalgae. Bioresour Technol 111:191-200

22. Davis R, Markham J, Kinchin C, Grundl N, Tan ECD, Humbird D (2016) Process design and economics for the production of algal biomass: algal biomass production in open pond systems and processing through dewatering for downstream conversion

23. M. Q. Frank, E. D., Han, J., Palou-Rivera, I., Elgowainy, A., \& Wang, "Life-cycle analysis of algal lipid fuels with the GREET model," 2011.

24. Kadam KL (2001) Microalgae production from power plant flue gas: environmental implications on a life cycle basis

25. Fagerstone KD (2011) Measurement of direct nitrous oxide emissions from microalgae cultivation under anoxic conditions. Environ Sci Technol 45: 9449-9456

26. Carter MS et al (2012) Air-water fluxes of $\mathrm{N} 2 \mathrm{O}$ and $\mathrm{CH} 4$ during microalgae (Staurosira sp.) cultivation in an open raceway pond. Environ Sci Technol 46: 10842-10848

27. "Ethiop sugar corporation," 2017. [Online]. Available: http://www.etsugar.gov. et/index.php/en/.

28. Mata TM, Martins AA, Caetano NS (2010) Microalgae for biodiesel production and other applications: a review. Renew Sust Energ Rev 14(1): 217-232

29. ANL; NREL; PNNL; "Renewable diesel from algal lipids: an integrated baseline for cost, emissions, and resource potential from a harmonized model. (No. ANL/ESD/12-4; NREL/TP-5100-55431; PNNL-21437). National Renewable Energy Laboratory. (NREL); Golden, CO (United States).," 2012.

30. W. J. Benemann, J. R, \& Oswald, "Systems and economic analysis of microalgae ponds for conversion of CO2 to biomass, PETC, Final Report (No.: FG22-93PC93204.) Sponsored by the Department of Energy, Department of Civil Engineering, Berkeley (CA 94720)." 1996.
31. E. Frank, M. Wang, and J. Han, "Introduction to algal fuel LCA in GREET1_ 2011". Center for Transportation Research, Argonne National Laboratory, 2011.

32. M. Nappa and P. Karinen, "Producing lipids, biogas and fertilizer from microalgae-conceptual design and techno-economic analysis," 2015.

33. Wiley PE, Campbell JE, McKuin B (2011) Production of biodiesel and biogas from algae: a review of process train options. Water Environ Res 83(4):326338

34. Shelef G, Sukenik A, Green M (1984) Microalgae harvesting and processing: a literature review

35. Wang B, Li Y, Wu N, Lan CQ (2008) CO2 bio-mitigation using microalgae. Appl Microbiol Biotechnol 79(5):707-718

36. C. S. Theegala, "Algal cell disruption and lipid extraction: a review on current technologies and limitations," in Algal Biorefineries, vol. 2, 2015, pp. 422438.

37. C. Lohrey, "Biodiesel production from microalgae: co-location with sugar mills," by no. August, 2012.

38. Halim R, Gladman B, Danquah MK, Webley PA (2011) Bioresource technology oil extraction from microalgae for biodiesel production Bioresour Technol 102(1):178-185

39. M. Zappi, R. Hernandez, D. Sparks, J. Horne, and M. Brough, "A review of the engineering aspects of the biodiesel industry," MSU E-TECH Lab. Rep., vol. ET-03-003, no. August, 2003.

40. Pokoo-Aikins G, Nadim A, El-Halwagi MM, Mahalec V (2010) Design and analysis of biodiesel production from algae grown through carbon sequestration. Clean Techn Environ Policy 12(3):239-254

41. Atadashi NMN, IM A, Aziz MK, A A, Sulaiman N (2011) Refining technologies for the purification of crude biodiesel. Appl Energy 88(12):4239-4251

42. Souza ME, Fuzaro G, Polegato AR (1992) Thermophilic anaerobic digestion of vinasse in pilot plant UASB reactor. War Sci Tech 25(7):213-222

43. Rajeshwari KV, Balakrishnan M, Kansal A, Lata K, Kishore WN (2000) State-ofthe-art of anaerobic digestion technology for industrial wastewater treatment. Renew Sust Energ Rev 4:135-156d

44. S. V Patil, "Alcohol technology lecture notes short term training programme for Ethiopian students," 2013.

45. España-Gamboa El, Mijangos-cortés JO, Hernández-Zárate G, Maldonado JAD, Alzate-Gaviria LM (2012) Methane production by treating vinasses from hydrous ethanol using a modified UASB reactor. Biotechnol Biofuels 5:1-9

46. España-Gamboa E, Mijangos-Cortes J, Barahona-Perez L, DominguezMaldonado J, Hernández-Zarate G, Alzate-Gaviria L (2011) Vinasses: characterization and treatments. Waste Manag Res 29(12):1235-1250

47. M. K. Daud et al., "Review of upflow anaerobic sludge blanket reactor technology: effect of different parameters and developments for domestic wastewater treatment," J. Chem., vol. 2018, 2018.

48. S. Chong, T. Kanti, A. Kayaalp, and H. Ming, "The performance enhancements of upflow anaerobic sludge blanket (UASB) reactors for domestic sludge treatment: a state-of-the-art review," Water Res, vol. 46, no. 11, pp. 3434-3470, 2012.

49. Aquino S, Pires EC (2016) Assessment of ozone as a pretreatment to improve anaerobic digestion of vinasse. Braz J Chem Eng 33(02):279-285

50. C. Held, M. Wellacher, and K. Robra, "Two-stage anaerobic fermentation of organic waste in CSTR and UFAF reactors," Bioresour Technol., vol. 81, no. ccccc, pp. 19-24, 2002

51. L. Mailin, L. González, I. Pereda, and O. Romero, "Anaerobic co-digestion of sugarcane press mud with vinasse on methane yield," Waste Manag., no. July, 2017.

52. Luostarinen S, Luste S, Sillanpää M (2009) Increased biogas production at wastewater treatment plants through co-digestion of sewage sludge with grease trap sludge from a meat processing plant. Bioresour Technol 100(1): 79-85

53. Agrawal H, Lalit K, HARADA, HIDEKI, OKUI N (1997) Treatment of dilute wastewater in a UASB reactor at a moderate temperature: performance aspects. J Ferment BIOENGLNEERIN 83(2):179-184

54. Park JH, Park JK (2003) Fate of methanol in an anaerobic digester. Korean J Chem Eng 20(3):509-516

55. L. Miroslav, Hutňan; Nina, Kolesárová; Igor, Bodík; Viera, Špalková; Michal, "Possibilities of anaerobic treatment of crude glycerol from biodiesel production," in 36th International Conference of Slovak Society of Chemical Engineering, 2009, pp. 156-1-156-13.

56. Fountoulakis MS, Petousi I, Manios T (2010) Co-digestion of sewage sludge with glycerol to boost biogas production. Waste Manag 30(10):1849-1853 
57. G. T. F. L. B. H. D. Stensel, Waste Water Engineering: Treatment and Reuse, Fourth Edi. McGraw-Hill, Inc, 2003.

58. R. Rajagopal, M. R. Choudhury, and N. Anwar, "Influence of pre-hydrolysis on sewage treatment in an up-flow anaerobic sludge BLANKET (UASB) reactor: a review," Water, pp. 3-7, 2019.

59. Ehimen EA, Sun ZF, Carrington CG, Birch EJ, Eaton-Rye JJ (2011) Anaerobic digestion of microalgae residues resulting from the biodiesel production process. Appl Energy 88(10):3454-3463

60. Mandal S, Mallick N (2009) Microalga Scenedesmus obliquus as a potential source for biodiesel production. Appl Microbiol Biotechnol 84(2):281-291

61. Q. Richmond, A., \& Hu, Ed., Handbook of microalgal culture, Second edt. John Wiley \& Sons, Ltd, 2013.

62. P. Brennan, L., \& Owende, "Biofuels from microalgae: towards meeting advanced fuel standards," in Advanced biofuels and bioproducts, Springer New York, 2013, pp. 553-599.

63. Stephenson AL, Kazamia E, Dennis JS, Howe CJ, Scott SA, Smith AG (2010) Life-cycle assessment of potential algal biodiesel production in the united kingdom: a comparison of raceways and air-lift tubular bioreactors. Energy Fuel 24(7):4062-4077

64. P. Singh, S. K. Gupta, A. Guldhe, I. Rawat, and F. Bux, "Microalgae isolation and basic culturing techniques," in Handbook of Marine Microalgae, Elsevier Inc., 2015, pp. 43-54

65. Ugwu CU, Aoyagi H, Uchiyama H (2008) Photobioreactors for mass cultivation of algae. Bioresour Technol 99(10):4021-4028

66. Pires JCM, Alvim-Ferraz MCM, Martins FG, Simões M (2012) Carbon dioxide capture from flue gases using microalgae: engineering aspects and biorefinery concept. Renew Sust Energ Rev 16(5):3043-3053

67. Rawat I, Kumar RR, Mutanda T, Bux F (2013) Biodiesel from microalgae: a critical evaluation from laboratory to large scale production. Appl Energy 103:444-467

68. M. Cooney, G. Young, and N. Nagle, "Extraction of Bio-oils from microalgae," Sep Purif Rev, vol. 38, no. 4, pp. 291-325, 2009.

69. Hirano A, Hon-nami K, Kunito S, Hada M, Ogushi Y (1998) Temperature effect on continuous gasification of microalgal biomass: theoretical yield of methanol production and its energy balance. Catal Today 45:399-404

\section{Publisher's Note}

Springer Nature remains neutral with regard to jurisdictional claims in published maps and institutional affiliations.

Ready to submit your research? Choose BMC and benefit from:

- fast, convenient online submission

- thorough peer review by experienced researchers in your field

- rapid publication on acceptance

- support for research data, including large and complex data types

- gold Open Access which fosters wider collaboration and increased citations

- maximum visibility for your research: over $100 \mathrm{M}$ website views per year

At BMC, research is always in progress.

Learn more biomedcentral.com/submissions 